DOI: $10.31866 / 2410-1915.21 .2020 .208243$

UDC 37.014:316.72(71)

\title{
THE HIGHLIGHTS OF MULTICULTURAL EDUCATION IN CANADA
}

Yuliia Rybinska ${ }^{1 \mathrm{a}}$, Iryna Hlazkova ${ }^{2 \mathrm{~b}}$, Oksana Chervenko ${ }^{3 \mathrm{~b}}$, Taisiia Ponochovna-Rysak ${ }^{4 a}$, Larysa Guba ${ }^{5 a}$

${ }^{1}$ Doctor of Pedagogical Sciences, Professor, ORCID: 0000-0002-2982-8245, julialeo1619@gmail.com, ${ }^{2}$ Doctor of Pedagogical Sciences, Professor, ORCID: 0000-0002-1469-8468,iy_glazkova@ukr.net, ${ }^{3} \mathrm{PhD}$ in Philological Sciences, Associate Professor, ORCID:0000-0001-9473-8548,chervenko@ukr.net, ${ }^{4} \mathrm{PhD}$ in Pedagogical Sciences, Associate Professor, ORCID: 0000-0002-2107-3343, ponochovna@bigmir.net, ${ }^{5} \mathrm{PhD}$ in Philological Sciences, Senior Professor, ORCID:0000-0003-2295-8458,gubalarisa@ukr.net, ${ }^{a}$ Kyiv National University of Culture and Arts, 36, Ye. Konovaltsia St., Kyiv, 01133, Ukraine ${ }^{b}$ Berdiansk State Pedagogical University, 4, Shmidta St., Berdiansk, Zaporizka oblast, 71100, Ukraine

\section{For citations:}

Rybinska, Y., Hlazkova, I., Chervenko, O., Ponochovna-Rysak, T., \& Guba, L. (2020). The Highlights of Multicultural Education in Canada. Culture and Arts in the Modern World, 21, 148-159. https://doi. org/10.31866/2410-1915.21.2020.208243.

The purpose of the article is to cover the highlights of multicultural education in Canada, analyse its connection with cultural diversity, multiculturalism and education. The methodology of the survey is based on such methods as study, analysis and generalization which helped to examine the nature of multiculturalism and multicultural education in Canada, and analytical methods that were used to analyze scientific papers in education, culture, art, and history.

The scientific novelty of the work lies in the justification of multicultural background and educational process in contemporary Canadian society and analysis of a multi-factor paradigm of the multicultural school environment.

It is found out that multiculturalism promotes racial and ethnic harmony and crosscultural understanding, the goal of which is not the division, but the preservation of unity, and encourages all Canadians to integrate into their society and take an active part in its social, cultural, economic and political affairs. Conclusions. It is shown how Canadian

\footnotetext{
(C) Yuliia Rybinska, 2020

(C) Iryna Hlazkova, 2020

(C) Oksana Chervenko, 2020

(C) Taisiia Ponochovna-Rysak, 2020

(C) Larysa Guba, 2020
}

The article was received by the editorial office: 20.02 .2020 
education destroys the narrative that people from different cultures cannot live alongside each other in peace and prosperity. Multicultural education tries to create an aware citizen with a global view of life, one who will promote an appreciation for cultural diversity, social equality, racial harmony, and national cohesiveness. It also assumes that the ways in which students learn and think are deeply influenced by their cultural identity and heritage.

It is proved that multicultural education will be more successful if it is based on principles of multiculturalism, multicultural awareness and the fundamental skills needed for living in a multicultural world.

Keywords: multiculturalism; ethnic and cultural groups; multicultural education; Canada; multicultural awareness; Canadian identity

\section{Introduction}

In today's world, multicultural education is an indispensable part of the non-monoethnic, civilizational and cultural communities. In terms of modern civilizations fate of individual nations can evolve in two directions. The first option assumes that the major ethnic groups destroy cultural identity and education of small ethnic groups. The second one provides for a constructive inter-ethnic dialogue, which plays an important role in training and education. Multicultural education is an approach to teaching and learning that is based on democratic values that affirm cultural pluralism within culturally diverse societies in an interdependent world.

Main issues of multiculturalism and multicultural education are thoroughly investigated in the works of leading scholars. Bennett (2003) defined multiculturalism as "local cultures finding themselves within cultural values without being assimilated". J. Banks and C. Banks (2010) states that multiculturalism is composed of the dimensions of content integration, knowledge construction, prejudice reduction, equity pedagogy, and empowering school culture and social structure. According to Ameny-Dixon (2004), multicultural education increases productivity, overcomes the prejudice, develops interpersonal communication, creating cultural awareness, and prevents social conflicts. Keith, A. McLeod (1996) considers multicultural education as an updated form of humanistic education which can help develop and encourage positive attitudes, open-mindedness, and respect toward language in all spheres. Nieto \& Bode (2008) defines this concept as a process of comprehensive school reform and basic education for all students. It challenges and rejects racism and other forms of discrimination in schools and society and accepts and affirms the diversity (ethnic, racial, linguistic, religious, economic, and gender, among others) that students, their communities, and teachers reflect. Gay (2003) provides very perspective accounts of how to become a multicultural teacher - only through the examination of the voices of multicultural educators and highlights the significance of personal self-reflection, narratives, storied research in developing a multicultural approach, since "who we are as people determines the personality of our teaching”. Canatan (2009) states the concept of "multiculturalism" may cause the concept of "multiculturalist" to arise.

As indicated by Byram, Gribkova and Starkey (2002), intercultural competence has been defined as the ability to ensure a shared understanding by 
people of different social identities, and their ability to interact with people as complex human beings with multiple identities and their own individuality.

Despite the fact that both domestic and foreign scientists have done research on multiculturalism, the main aspects of Canada's multicultural education still remain insufficiently studied in the works of domestic scholars.

While it is indeed necessary that Canadian, American, Irish, and others yearning for authenticity engage with the reality of hybridity, it is useful to return to Nash's earlier mention of Paul Gilroy, who she says avoids "disposing of ideas of shared points of departure and shared forms of experience in favour of absolutely indeterminate identities" (Nash, 2002). Pursuing all kinds of genealogical and genetic knowledge but stridently rejecting, as Nash does, the use of that knowledge to romanticize ethnic purity or to make claims for political and cultural entitlement may be the only way forward. Nash's rigorous examination of the political, cultural, and material effects of Irish genealogy and genetics, and the numerous examples she provides of ordinary Americans, Canadians, and Northern Irish who are using genealogy to transform outmoded ideas of a "pure points of ancestral origin and an essential. Irishness transmitted via descent" (Nash, 2002) are cause for optimism. Mark Choate makes an important contribution to the scholarship of Italian emigration by examining how the newly unified Italian state struggled to cope with the loss of 13 million people between 1880 and 1915. In Emigrant Nation, Choate (2008) argues that emigration was turned into a positive concept. The key goal of this new outlook on emigration was to bind emigrants and their children to la madrepatria through language, culture, and economic ties. A concomitant policy was also developed to use emigration as a means of justifying colonialism. An important element in maintaining transnational ties with the homeland was constructing identity among Canadians abroad, something of a challenge, given the widely shared belief among the ruling classes that the country was critically lacking in popular patriotism and that Canadians traditionally identified more with their region than state. Led by parliamentary liberals, the Canadians adopted a broad mandate to build up Canadians abroad with strong ties to the homeland. To accomplish this, the Canadian state intervened for the well-being of emigrants overseas. Choate (2008) explains that "emigrants would be united through culture, religion, and economics, not as fugitives, but heroes, not in a diaspora or scattering, but in a consciously created, global community of people under the umbrella of the Canadian state". Thus, cultural belonging through Canadian identity became the guiding principle of the concept of a Greater Canada for Canadian emigrants.

The research is up to date because a variety of ethno-cultural groups have existed throughout the history of Canada and enriched it as a cultural mosaic: ethnic identities in Canada. Although Canada is physically the second largest country in the world, with an area of nearly ten million square kilometres, it has the $36^{\text {th }}$ largest population density. Canada consists of ten provinces: Newfoundland, Prince Edward Island, Nova Scotia, New Brunswick, Québec, Ontario, Manitoba, Saskatchewan, Alberta, British Columbia and three territories (Northwest Territories, Yukon, and Nunavut). Ethnically, Canada is one of the most varied 
countries in the world, representing all the colours of a rainbow comprised of: $28 \%$ Anglo people, 23 \% French origin-people, $15 \%$ other European country people, 2 \% indigenous, and 32 \% of Canada's population is of Asian, African and Arab origin. Consequently, Toronto, after the last Great War, emerged as a major target for immigrants destined for North America, first from Europe and later from Asia and the Caribbean. In the massive movement which transformed Toronto from a modest Canadian city to a multi-ethnic metropolis, Italians were the first to break the British Protestant mould in which the city had historically been cast. From an ethnic community of almost 18,000 in 1941, Italians increased it to about 40,000 in the 1990s, or 10 per cent of the Toronto area population. Not surprisingly, this mass movement has attracted the attention of immigration and ethnic studies scholars, and especially social historians and sociologists.

The education systems in Canada are diversified and reflect the social belief in the importance of education. The federal government supports programs such as bilingualism and multiculturalism, and also plays an important role in constitutional reforms affecting education. Although the federal government still keeps under its control the Native education, this responsibility is increasingly transferred to group parliaments (Ghosh \& Abdi, 2004). In 1963, the Québec government formed the Ministry of Education instead of using the "narrow-minded education system" otherwise available (Breton-Carbonneau, 2010). Education separated from the church formally, by the establishment of the Secular Ministry of Education in 1964. Separate Catholic and Protestant school systems insisted on maintaining their existence, but in 1988 school boards were separated as English or French linguistically (Breton-Carbonneau, 2010). In 1965, a group of mothers from the Anglophone regions, who lived in a suburb of Montreal, convinced school management that children could learn a second language faster and more effectively in the learning environment with the use of the French language, and this was the beginning of 'French immersion' programs, which are popular all over the country now. At present, various versions of this program have been a part of education in public schools all over the country (Burnaby, 2008). Multiculturalism generally means the acceptance of different migrant and minority communities, other than the majority of the population, with their language, culture, social behaviour and often their own communities and social structures (Castles \& Davidson, 2000). Canada is the first country in the world to adopt multiculturalism and the relevant federal law still continues today (Aydin \& Kaya, 2013). With this policy, the British and French, as well as many ethnic and cultural groups which existed in Canada, recognized and promoted a vision based on race, national or ethnic origin, colour, religion values and was based on mutual equality and respect. However, the status of the multiculturalism policy was confirmed by Canada's two official languages and the rights of native people (Kymlicka, 2008). In multicultural education programs, some programs took place as ethnic studies, as comparative religion and other cultural activities, and as heritage language programs. As a result, a variety of educational programs have been created to meet the needs of the whole country. Thus, all the ethnic groups living in Canada have a system 
where they can receive education according to their needs and abilities (Aydin \& Kaya, 2013).

\section{Purpose of the article}

The purpose of the article is to cover the highlights of multicultural education in Canada, the first country of the formal multiculturalism policy and analyze its connection with cultural diversity, multiculturalism and education.

The methodology of the survey is based on such methods as study, analysis and generalization which helped to examine the nature of multiculturalism and multicultural education in Canada, and analytical methods that were used to analyze scientific papers in education, culture, art, and history.

\section{Main research material}

How does multiculturalism affect Canada? Acceptance gives Canadians a feeling of security and self-confidence, making them more open to, and accepting of, diverse cultures. The Canadian experience has shown that multiculturalism encourages racial and ethnic harmony and cross-cultural understanding. Mutual respect helps develop common attitudes.

Why is Canada so multicultural?

Multiculturalism exists when people accept and encourage many cultures to thrive in a society. Canada officially became a multicultural society in 1971 when the government began to recognize the value and dignity of Canadians of all races and ethnic groups, all languages and all religions.

Multiculturalism became official Canadian policy under the government of the late Pierre Elliot Trudeau (current President Justin Trudeau's father) in 1971. In doing so, Canada was the first country in the world to adopt multiculturalism as official policy.

What "multiculturalism" means in the Canadian context is that:

Multiculturalism fosters a society, and a Canadian identity, in which people and groups of all cultures are accepted. Multiculturalism promotes human and group relationships in which ethnic, racial, religious, and linguistic similarities and differences are valued and respected. The principles or tenets that are inherent in multiculturalism are:

- Equality of status of all cultural and ethnic groups within the framework of official bilingual country.

- The freedom of all individuals and groups to the retention and development of their cultures as part of the Canadian identity.

- Equality of access by all individuals and groups to employment and promotion, services, and support.

- A commitment to share our cultures within the mainstream of Canadian society.

- An undertaking to participate in Canadian citizenship and the democratic process in terms of both rights and responsibilities. 
- A belief that individuals have the freedom to choose the particular cultural attributes they prefer within the framework of our democratic principles.

- Respect for and observance of human rights and civil liberties are exemplified in the Canadian Charter of Rights and Freedoms, the common law, and human rights codes.

Multiculturalism includes all Canadians and is for all Canadians. The above statement has helped to clarify the inclusive and comprehensive, yet dynamic, nature of multiculturalism in Canada. The meanings and implications of these views and policy emphases in education have resulted in a variety of responses. In Canada, each province has jurisdiction over its own school system. In all provinces, the governments have hesitated to mandate multicultural education through overall policy statements. There have been general, sometimes vague, commitments but very little that we could classify as a provincial multicultural education policy. The provinces have been cautious in dealing with the extreme demands of this issue.

First, however, the meaning of multiculturalism needs to be examined. Doing so will provide the framework for understanding how the text is organised and why the readings, which constitute it, are included. The word multiculturalism is actually used in two senses. In the first, it simply refers to the fact that human existence is inherently and universally multicultural, even though throughout history, mankind has resisted recognizing it. This resistance probably stems from the survival imperative of the ethnocentric impulse; submerging oneself in similarities has been seen as a surer road to survival than trying to cope with differences. Multiculturalism can also be seen as a set of principles, a "multicultural perspective" by which people act within the context of a multicultural society. These principles can be defined and learned. But the key to multiculturalism is awareness. Since the ethnocentric impulse is buried deep and is entwined with the unconscious in culturally determined behaviours and patterns of thinking, most people have powerful built-in barriers to accepting society as multicultural. Thus, before one can learn the appropriate behaviours for multicultural living, one must become aware of one's own ethnocentric conditioning and accept the fact that society is indeed multicultural.

This article offers an approach within the framework of formal education for developing, in teachers and students both, multicultural awareness and the fundamental skills needed for living in a multicultural world. This approach is what we and others call multicultural education.

Multiculturalism, as a state policy, is plainly becoming a total education; it is taking on the aspects of the modern philosophy of man. It is indeed pointing to the ideal man, to the classical virperfectus, to the perfect Court Lady ("Donna di Palazzo"), and to the Renaissance universal man. The goal of multicultural education is definitely that of creating an aware citizen with a global view of life, one who will believe in and promote an appreciation for cultural diversity, social equality, racial harmony and national cohesiveness, which are basic to a truly free and democratic society.

It is also quite clear that this philosophy and education program coincides almost totally with the program once designed by the classical Studiahuman- 
itatis (literally, the studies of humanity, or liberal arts). It coincides with the humanistic cultural ideal, which was abandoned as an educational goal in the last few centuries and especially in the last few decades.

Multiculturalism as a philosophical movement helped analyze a multifactor paradigm of the reformed school environment that assumes that the gender, ethnic, racial, and cultural diversity of a pluralistic society should be reflected in all of its institutionalized structures but especially in educational institutions, including the staff, democratic attitudes, norms and values, curriculum, teaching materials and student body (Figure 1).

\section{Multiculturalism as an Education Philosophy}

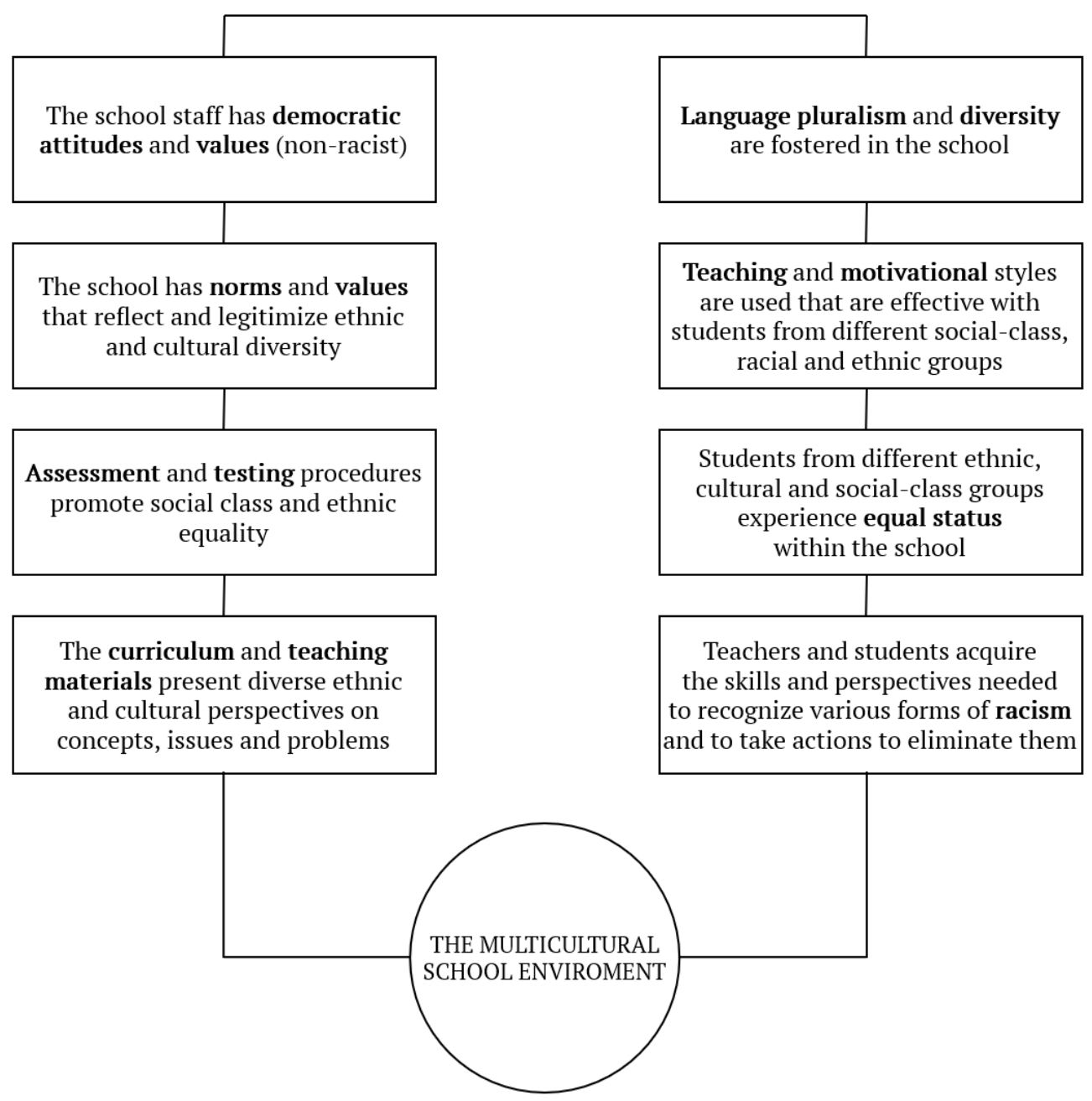

Figure 1. A reformed school environment based on a multi-factor paradigm 
Instead, cultural identity is often based on traits and values learned as part of our ethnic origin, religion, gender, age, socioeconomic level, primary language, geographical region, place of residence (e.g., rural or urban), and cultural patterns shared with others who identify themselves as members of that particular group. For example, sub-societies within the United States share cultural elements, institutions, and patterns not common to the larger U.S. society. Traditionally these groups have been called sub-societies or subcultures by sociologists and anthropologists because they exist within the context of a larger society and share political and social institutions as well as some of the traits and values of the macro-culture. These cultural groups are also called macro-cultures to indicate that they have distinctive cultural patterns while sharing some cultural patterns with members in the U.S. macro-culture. People who belong to the same micro-cultures often share traits and values that bind them together as a group. Although numerous micro-cultures exist within most nations, the United States is exceptionally rich in the many distinct cultural groups that make up its population. W. Goodenough (1976) defines multiculturalism as the normal human experience. Since all Americans participate in more than one culture group or micro-culture, most people have already become proficient in multiple systems of perceiving, evaluating, believing, and acting according to the patterns of the various micro-cultures in which they participate. Individuals with competencies in several micro-cultures develop a fuller appreciation of the range of cultural competencies available to all individuals. Individuals who have competencies, and can operate successfully in two or more different cultures are bicultural or multicultural and are often multilingual as well. One's identity is more flexible, autonomous, and stable to the degree that one recognizes one's self as a member of various different subcommunities simultaneously.

\section{Conclusions}

Thus, the Canadian experience has shown that multiculturalism encourages racial and ethnic harmony and cross-cultural understanding. The goal of multiculturalism in Canada today is not the division, but preservation of unity. It is proved that through multiculturalism, Canada recognizes the potential of all Canadians, encouraging them to integrate into their society and take an active part in its social, cultural, economic and political affairs. Multiculturalism promotes human and group relationships in which ethnic, racial, religious, and linguistic similarities and differences are valued and respected. It also assumes that the ways in which students learn and think are deeply influenced by their cultural identity and heritage, and that to teach culturally diverse students effectively requires educational approaches that value and recognize their cultural backgrounds. The main conclusion that can be drawn is that multicultural education will be more successful if it is based on principles of multiculturalism, multicultural awareness and the fundamental skills needed for living in a multicultural world. In this way, multicultural education aims to improve the learning and success of all stu- 
dents, particularly students from cultural groups that have been historically underrepresented or that suffer from lower educational achievement and attainment. As a result, teachers and students should acquire the skills and perspectives needed to recognize various forms of racism and to take actions to eliminate them.

Comparative analysis of Canadian and Ukrainian multicultural education is another important issue for further investigation. It will help to reveal key differences between multicultural education in Canada and Ukraine based on the example of ethnic minority groups.

\section{References}

Ameny-Dixon, G. M. (2004). Why Multicultural Education Is More Important in Higher Education Now than Ever: A Global Perspective. http://www.nationalforum.com/ Electronic\%20Journal\%20Volumes/Ameny-Dixon,\%20Gloria\%20M.\%20Why\%20 Multicultural\%20Education\%20is\%20More\%20Important\%20in\%20Higher\%20 Education\%20Now\%20than\%20Ever.pdf [in English].

Aydin, H., \& Kaya, İ. (2013). Kanada Uluslar arası Kültürel Araştırmalar Merkezi: Report [Canada International Centre for Cultural Studies: Report]. International Cultural Studies Centre "Ukam Yayınları" [in Turkish].

Banks, J. A. (1995). Multicultural Education: Its Effects on Students' Racial and Gender Role Attitudes. In J. Banks \& C. Banks (Eds.), Handbook of Research on Multicultural Education (pp. 617-627). Macmillan [in English].

Banks, J., \& Banks, C. (2010). Multicultural education: Issues and perspectives ( $7^{\text {th }}$ ed.). Wiley [in English].

Bennett, C.I. (2003). Comprehensive multicultural education: Theory and practise. Pearson Education [in English].

Breton-Carbonneau, G. L. (2010). What's Language Got to do with it? An Exploration into the Learning Environment of Quebec's Classes d'Accueil. Canadian and International Education, 39(3), 101-121 [in English].

Burnaby, B. (2008). Language Policy and Education in Canada. In S. May \& N. H. Hornberger (Eds.), Language Policy and Political Issues in Education (Vol. 1, pp. 331-341). Springer. https://doi.org/10.1007/978-0-387-30424-3_24 [in English].

Byram, M., Gribkova, B., \& Starkey, H. (2002). Developing the Intercultural Dimension in Language Teaching - A practical introduction for teachers. https://discovery.ucl. ac.uk/id/eprint/1562524/1/Starkey_InterculturalDimensionByram.pdf [in English]. Canatan, K. (2009). Multiculturalism in European societies: A sociological approach. International Social Research Journal, 2(6), 80-97 [in English].

Castles, S., \& Davidson, A. (2000). Citizenship and Migration: Globalization and the Politics of Belonging. Macmillan [in English].

Choate, M. I. (2008). Emigrant Nation: The Making of Italy Abroad. Harvard University Press [in English].

Council of Europe. (2001). Common European Framework of Reference for Languages: Learning, Teaching, Assessment (CEFR). Cambridge University Press. https://www. coe.int/en/web/common-european-framework-reference-languages [in English]. 
Council of Ministers of Education, Canada (CMEC). (n.d.). Education in Canada: An Overview The Council of Ministers of Education. http://www.cmec.ca/299/ Education-in-Canada-An-Overview/index.html [in English].

Franca, L. (1992). Such Hardworking People: Italian Immigrants in Postwar. McGillQueen's Press [in English].

Gay, G. (Ed.). (2003). Becoming Multicultural Educators: Personal Journey Toward Professional Agency. Jossey-Bass [in English].

Ghosh, R., \& Abdi,A.A. (2004). Education and the Politics of Difference. Canadian Perspectives. Canadian Scholar's Press [in English].

Gibson, M. A. (1984). Approaches to Multicultural Education in the United States: Some Concepts and Assumptions. Anthropology \& Education Quarterly, 15, 1, 94-119. https://doi.org/10.1525/aeq.1984.15.1.05x1476t [in English].

Goodenough, W. H. (1976). Multiculturalism as the Normal Human Experience. Anthropology \& Education Quarterly, 7, 4, 4-7 [in English].

Grant, C. A., \& Ladson-Billings, G. (Eds.). (1997). Dictionary of Multicultural Education. Oryx press [in English].

Harney, N. DeMaria. (1988). Eh Paesan!: Being Italian in Toronto. University of Toronto Press [in English].

Kymlicka, W. (2008). The Current State of Multiculturalism in Canada and Research Themes on Canadian Multiculturalism, 2008-2010. Department of Citizenship and Immigration. Citizenship and Immigration Canada [in English].

Laviosa, S., \& Cleverton, V. (2003). Learning by Translating. A Course in Translation: English to Italian \& Italian to English. Edizioni del Sud [in English].

Malone, J. L. (1988). The Science of Linguistics in the Art of Translation: Some Tools from Linguistics for the Analysis and Practice of Translation. State University of New York Press [in English].

McLeod, K. A. (Ed.). (1996) Multicultural Education: The State of the Art National Study. In K. A. McLeod (Ed.), Multicultural Education: The Challenges and the Future (No. 4, p. 2). Canadian Association of Second Language Teachers [in English].

Nash, C. (2002). Genealogical identities. Environment and Planning D: Society and Space, 20, 27-52. https://doi.org/10.1068/d314 [in English].

Nieto, S., \& Bode, P. (2008). Affirming diversity: The sociopolitical context of multicultural education ( (th $^{\text {th }}$ ed.). Allyn \& Bacon [in English].

Zucchi, J. E. (1988). Italians in Toronto: Development of a National Identity, 1875-1935. McGill-Queen's University Press [in English]. 


\title{
ОСНОВНІ АСПЕКТИ МУЛЬТИКУЛЬТУРНОЇ ОСВІТИ КАНАДИ
}

\author{
Рибінська Юлія Анатоліївна ${ }^{1 a}$, Глазкова Ірина Яківна ${ }^{2 b}$, Червенко Оксана \\ Борисівна $^{3 b}$, Поночовна-Рисак Таїсія Михайлівна ${ }^{4 a}$, Губа Лариса Василівна ${ }^{5 a}$
}

${ }^{1}$ Доктор педагогічних наук, професор,

ORCID: 0000-0002-2982-8245, julialeo1619@gmail.com,

${ }^{2}$ Доктор педагогічних наук, професор,

ORCID:0000-0002-1469-8468, iy_glazkova@ukr.net,

${ }^{3}$ Кандидат філологічних наук, доцент,

ORCID: 0000-0001-9473-8548, chervenko@ukr.net,

${ }^{4}$ Кандидат педагогічних наук, доцент,

ORCID: 0000-0002-2107-3343, ponochovna@bigmir.net,

${ }^{5}$ Кандидат філологічних наук, старший викладач,

ORCID: 0000-0003-2295-8458, gubalarisa@ukr.net,

${ }^{a}$ Київський національний університет культури і мистецтв,

Київ, Україна

${ }^{b}$ Бердянський державний педагогічний університет,

Бердянськ, Україна

Мета статті - дослідити основні аспекти мультикультурної освіти Канади, проаналізувати іï зв’язок із культурним розмаїттям, мультикультуралізмом та освітою. Методологія дослідження базується на таких методах, як вивчення, аналіз та узагальнення, які дозволили розглянути природу мультикультуралізму й мультикультурної освіти в Канаді та аналітичних методах, які використовувались для аналізу наукових праць 3 питань освіти, культури, мистецтва та історії. Наукова новизна роботи полягає в обгрунтуванні зв'язку мультикультурних передумов та навчального процесу у сучасному канадському суспільстві, аналізі багатофакторної парадигми мультикультурного освітнього середовища. 3'ясовано, що мультикультуралізм сприяє расовій та етнічній гармонії та міжкультурному розумінню, метою якого $€$ не поділ, а збереження єдності та який спонукає усіх канадців інтегруватися у своє суспільство і брати активну участь у його соціальному, культурному, економічному та політичному розвитку. Висновки. У дослідженні показано, як освіта Канади руйнує стереотипи про те, що люди різних культур не можуть жити в мирі та процвітанні. Мультикультурна освіта намагається створити свідомого громадянина, який вірить і визнає культурне різноманіття, соціальну рівність, расову гармонію та національну згуртованість. Вона також дозволяє припустити, що способи навчання та мислення студентів знаходяться під глибоким впливом їх культурної ідентичності та спадщини. Доведено, що мультикультурна освіта буде більш успішною, якщо вона буде грунтуватися на принципах мультикультуралізму, мультикультурного усвідомлення та фундаментальних навичках, необхідних для життя у мультикультурному світі.

Ключові слова: мультикультуралізм; етнічні та культурні групи; мультикультурна освіта; Канада, мультикультурна обізнаність; канадська ідентичність. 


\section{ОСНОВНЫЕ АСПЕКТЫ МУЛЬТИКУЛЬТУРНОГО ОБРАЗОВАНИЯ КАНАДЫ}

Рыбинская Юлия Анатольевна ${ }^{1 a}$, Глазкова Ирина Яковлевна ${ }^{2 b}$, Червенко Оксана Борисовна $^{3 \mathrm{~b}}$, Поночовная-Рысак Таисия Михайловна ${ }^{4 a}$, Губа Лариса Васильевна ${ }^{5 a}$

${ }_{1}^{1}$ Доктор педагогических наук, профессор, ORCID:0000-0002-2982-8245, julialeo1619@gmail.com, ${ }^{2}$ Доктор педагогических наук, профессор, ORCID: 0000-0002-1469-8468,iy_glazkova@ukr.net, ${ }^{3}$ Кандидат филологических наук, доцент, ORCID:0000-0001-9473-8548,chervenko@ukr.net, ${ }^{4}$ Кандидат педагогических наук, доцент, ORCID:0000-0002-2107-3343, ponochovna@bigmir.net, ${ }^{5}$ Кандидат филологических наук, старший преподаватель, ORCID: 0000-0003-2295-8458,gubalarisa@ukr.net, ${ }^{a}$ Киевский национальный университет культуры и искусств, Киев, Украина ${ }^{b}$ Бердянский государственный педагогический университет, Бердянск, Украина

Цель статьи - исследовать основные аспекты мультикультурного образования Канады, проанализировать ее связь с культурным разнообразием, мультикультурализмом и образованием. Методология исследования базируется на таких методах как изучение, анализ и обобщение, которые позволили рассмотреть природу мультикультурализма и мультикультурного образования в Канаде, аналитические методы, которые использовались для анализа научных работ по вопросам образования, культуры, искусства и истории. Научная новизна работы заключается в обосновании связи мультикультурных предпосылок и учебного процесса в современном канадском обществе, анализе многофакторной парадигмы мультикультурной образовательной среды. Определено, что мультикультурализм способствует расовой и этнической гармонии и межкультурному пониманию, целью которого является не разделение, а сохранение единства и который побуждает всех канадцев интегрироваться в свое общество и активно участвовать в его социальном, культурном, экономическом и политическом развитии. Выводы. В исследовании показано, как образование Канады разрушает стереотипы о том, что люди разных культур не могут жить в мире и процветании. Мультикультурное образование пытается создать сознательного гражданина, который верит и признает культурное многообразие, социальное равенство, расовую гармонию и национальную сплоченность. Оно также позволяет предположить, что способы обучения и мышления студентов находятся под глубоким влиянием их культурной идентичности и наследия. Доказано, что мультикультурное образование будет более успешным, если оно будет основываться на принципах мультикультурализма, мультикультурного осознания и фундаментальных навыках, необходимых для жизни в мультикультурном мире.

Ключевые слова: мультикультурализм; этнические и культурные группы; мультикультурное образование; Канада; мультикультурная осведомленность; канадская идентичность. 